Decentering Citizenship 



\section{Decentering Citizenship}

GEN DER, LA B OR, A N D M IGRANT

RIGHTS IN SOUTH KOREA

Hae Yeon Choo 
Stanford University Press

Stanford, California

(C) 2016 by the Board of Trustees of the Leland Stanford Junior University. All rights reserved.

No part of this book may be reproduced or transmitted in any form or by any means, electronic or mechanical, including photocopying and recording, or in any information storage or retrieval system without the prior written permission of Stanford University Press.

Portions of Chapter 6 previously appeared in the article "In the Shadow of Working Men: Gendered Labor and Migrant Rights in South Korea" in Qualitative Sociology. It is reprinted here with permission.

Portions of Chapter 7 previously appeared in the article "The Cost of Rights: Migrant Women, Feminist Advocacy, and Gendered Morality in South Korea" in Gender \& Society. It is reprinted here with permission.

Printed in the United States of America on acid-free, archival-quality paper

Library of Congress Cataloging-in-Publication Data

Names: Choo, Hae Yeon, author.

Title: Decentering citizenship : gender, labor, and migrant rights in South Korea / Hae Yeon Choo.

Description: Stanford, California : Stanford University Press, 2016.| Includes bibliographical references and index.

Identifiers: LCCN 2015044865| ISBN 978080479I274 (cloth : alk. paper) |

ISBN 9780804799669 (pbk. : alk. paper) | ISBN 9780804799607 (e-book)

Subjects: LCSH: Women foreign workers-Civil rights_Korea (South) | Foreign workers, Filipino-Civil rights_-Korea (South) | Women foreign workers—Korea (South) Social conditions. | Foreign workers, Filipino—Korea (South)—Social conditions. | Citizenship_Korea (South) | Korea (South)_Emigration and immigration. | Philippines-Emigration and immigration.

Classification: LCC HD6057.5.K6 C46 2016 | DDC 323.3/224-dc23

LC record available at http://lccn.loc.gov/2015044865 
For my parents 
